\title{
Determination of suitable housekeeping genes for normalisation of quantitative real time PCR analysis of cells infected with human immunodeficiency virus and herpes viruses
}

\author{
Sarah Watson ${ }^{1}$, Sarah Mercier ${ }^{1}$, Chris Bye ${ }^{2}$, John Wilkinson ${ }^{3}$, \\ Anthony L Cunningham ${ }^{1}$ and Andrew N Harman*1
}

Address: ${ }^{1}$ Centre for Virus Research, Westmead Millennium Institute, Sydney, Australia, ${ }^{2}$ The Howard Florey Institute, University of Melbourne, Melbourne, Australia and ${ }^{3}$ Biotron Limited, Centre for Immunology, St. Vincent's Hospital, Sydney, Australia

Email: Sarah Watson - sarahlouise53@hotmail.com; Sarah Mercier - sarah_mercier@wmi.usyd.edu.au; Chris Bye - cbye@hfi.unimelb.edu.au; John Wilkinson - john_wilkinson@cfi.unsw.edu.au; Anthony L Cunningham - tony_cunningham@wmi.usyd.edu.au; Andrew N Harman* - andrew_harman@wmi.usyd.edu.au

* Corresponding author

Published: 3 December 2007

Virology Journal 2007, 4:130 doi:10.1186/1743-422X-4-130

This article is available from: http://www.virologyj.com/content/4/I/130

(C) 2007 Watson et al; licensee BioMed Central Ltd.

This is an Open Access article distributed under the terms of the Creative Commons Attribution License (http://creativecommons.org/licenses/by/2.0), which permits unrestricted use, distribution, and reproduction in any medium, provided the original work is properly cited.
Received: 10 October 2007

Accepted: 3 December 2007

\begin{abstract}
The choice of an appropriate housekeeping gene for normalisation purposes has now become an essential requirement when designing QPCR experiments. This is of particular importance when using QPCR to measure viral and cellular gene transcription levels in the context of viral infections as viruses can significantly interfere with host cell pathways, the components of which traditional housekeeping genes often encode. In this study we have determined the reliability of 10 housekeeping genes in context of four heavily studied viral infections; human immunodeficiency virus type I, herpes simplex virus type I, cytomegalovirus and varicella zoster virus infections using a variety of cell types and virus strains. This provides researchers of these viruses with a shortlist of potential housekeeping genes to use as normalisers for QPCR experiments.
\end{abstract}

\section{Background}

Quantitative real-time PCR (QPCR) is an invaluable tool for the measurement of target nucleic acid sequences in clinical diagnostics and research. The technique is capable of the relative or absolute quantification of RNA or DNA sequences in a single sample over a large dynamic range with extreme sensitivity and accuracy. In virology and immunology QPCR is used for the relative measurement of virus and host transcription (gene expression) profiles in response to viral infection and in the quantification of viral load in clinical samples and in research [1].

The sensitivity and accuracy of results obtained by QPCR are dependent on a reliable reference within each sample to normalise for sample to sample and run to run variation [2]. These variations arise from differences in nucleic acid integrity, the efficiency of the reverse transcription of RNA to cDNA and the amount of sample loaded. References for normalising sample and run variation include the use of total nucleic acid concentrations, rRNA concentrations or the simultaneously measurement of the expression of an individual or select group of genes termed 'housekeeping' genes, which has become by far the most commonly used method and is the most reliable [3]. Housekeeping genes are used under the assumption that their expression is unchanged in response to the experimental conditions being investigated. Therefore a major factor when using QPCR is the selection of 
appropriate control genes, as any variation in the expression of the reference gene between sample groups will reduce the sensitivity of the assay to detect changes in the expression of genes of interest and may also produce artificial changes [3]. Traditionally glyceraldehyde 3phosphate dehydrogenase (GAPDH) and $\beta$-actin (BACT) have been most commonly used, however many recent reports have shown that the expression of these genes can be variable under several experimental conditions, making them inappropriate for use as normalisers [4-7]. In reality no cellular gene maintains constant expression levels under all conditions and the evaluation of an appropriate control gene to normalise QPCR data is therefore an essential requirement when designing QPCR experiments using new experimental conditions [8]. This is especially the case when investigating the effects of viruses on host cell gene expression as viruses can interfere with host cell pathways, the components of which traditional housekeeping genes often encode. These include cell cycle, metabolism, DNA replication and transcription, in order to aid their replication cycle [9-11]. Studies have been carried out to determine reliable housekeeping genes in cells infected with a variety of viruses $[7,12]$, however to date no such study has been carried out in cells infected with human immunodeficiency virus (HIV) or the herpes viruses, herpes simplex virus (HSV) and varicella zoster virus (VZV). Thus, in this study we have investigated the suitability of 10 commonly used housekeeping genes for use as QPCR normalisers in a variety of cell types infected with a variety of strains of HIV-1, HSV-1, VZV and cytomegalovirus (CMV) compared to mock infected cells.

\section{Results}

A range of cell lines and primary cells were infected with HIV-1 (BaL, NL4.3, RFW strains), HSV-1 (NC-1 strain), CMV (Toledo and Towne strains) and VZV (Schenke strain) and harvested at the earliest time of maximal productive infection as illustrated in Table 1. The expression levels of 10 commonly used QPCR normalisation genes in both and mock and virally infected cells was determined by QPCR. The housekeeping genes investigated were beta-2microglobulin (B2M), peptidylprolyl isomerase A (PPIA), eukaryotic translation elongation factor 1 gamma (EEF1G), succinate dehydrogenase complex subunit A (SDHA), GAPDH, hydroxymethyl-bilane synthase (HMBS), TATA box-binding protein (TBP), 18s Ribosomal RNA (18sRNA), phosphoglycerate kinase 1 (PGK1), and BACT.

In order to accurately ascertain which housekeeping genes would be most reliable for use as normalisers in QPCR we subjected the data to analysis using the GeNorm tool [13] (Table 2). Using the results from the GeNorm analysis it was possible to list the housekeeping genes in order of reliability in the context of each viral infection (Table 3). 18sRNA was the least reliable reference gene as it had had the highest $\operatorname{sum}_{\mathrm{v}}$ value (13.26) which represents the standard deviation (SD) of reference gene expression over all viral infections investigated. Correspondingly it was either the least or second least reliable gene in 9 of the 10 experimental settings. Additionally BACT and HMBS also had high sum ${ }_{\mathrm{v}}$ values of 10.51 and 9.65 respectively, indicating that these genes are generally less reliable for use as normalisers for QPCR assays. According to this analysis the most reliable overall reference gene was PP1A with a $\operatorname{sum}_{\mathrm{v}}$ value of 7.41 and the most reliable gene in 7 of the 10 viral infections. Other genes with low sum $v$ values were SDHA (8.91), GAPDH (8.74), TBP (9.06) and EEF1G (9.16), though in the context of HSV-1 $1_{\mathrm{NC} 1}$ infected HELA cells EEF1G was identified as the least reliable gene. In the case of CMV an almost identical pattern in reliability was observed in infected primary HFF cells regardless of differences in the virus strain used and a very similar pattern was also seen in $\mathrm{VZV}_{\text {Schenke }}$ infected cells despite differences in the origin of the primary cell types used for infection. Though the expression pattern of reference genes in HELA and HEP2 cells infected with HSV-1 ${ }_{\mathrm{NC}-1}$ were also similar, it is of note that in HEP2 cells GAPDH was the second most reliable gene whereas in HELA cells it was the third most unreliable. The expression pattern of reference genes in cells infected with HIV-1 was also similar though greater differences were detected compared to the other

Table I: Viral strains, infection and cell culture conditions

\begin{tabular}{|c|c|c|c|c|c|}
\hline Virus & Strain & Cell Type & Time Point & MOI & $\%$ Infection \\
\hline HIV-I & $\mathrm{BaL}$ & MDDC & $48 \mathrm{hr}$ & 3 & $>30$ \\
\hline HIV-I & NL4.3 & HELA & $48 \mathrm{hr}$ & 3 & $>70$ \\
\hline HIV-I & NL4.3 & HUT78 & $48 \mathrm{hr}$ & 3 & $>70$ \\
\hline HIV-I & RFW & HUT78 & $48 \mathrm{hr}$ & 3 & $>80$ \\
\hline HSV-I & $\mathrm{NCl}$ & HELA & $18 \mathrm{hr}$ & 3 & $>95$ \\
\hline HSV-I & $\mathrm{NCl}$ & HEP2 & $18 \mathrm{hr}$ & 3 & $>95$ \\
\hline VZV & Schenke & MDDC & $72 \mathrm{hr}$ & 0.3 & $>30$ \\
\hline VZV & Schenke & HFF & $72 \mathrm{hr}$ & 0.3 & $>60$ \\
\hline CMV & Toledo & HFF & $72 \mathrm{hr}$ & 3 & $>90$ \\
\hline CMV & Towne & HFF & $72 \mathrm{hr}$ & 3 & $>90$ \\
\hline
\end{tabular}


Table 2: Results of GeNorm analysis

\begin{tabular}{|c|c|c|c|c|c|c|c|c|c|c|c|c|}
\hline Virus & Cell & B2M & PPIA & EEFIG & SDHA & GAPDH & HMBS & I 8sRNA & PGKI & B-ACT & TBP & sum $_{\text {RGC }}$ \\
\hline $\mathrm{HIV}-\mathrm{I}_{\mathrm{BaL}}$ & MDDC & 0.98 & 0.78 & 1.04 & 1.26 & 0.83 & 0.84 & 0.98 & 1.09 & $\mathrm{I} .45$ & 0.97 & 10.22 \\
\hline $\begin{array}{l}\text { HIV- } \\
\mathrm{I}_{\mathrm{NL} 4.3}\end{array}$ & HELA & 0.84 & 0.53 & 0.75 & 0.88 & 0.60 & 0.84 & 0.93 & 0.78 & 0.90 & 0.72 & 7.77 \\
\hline $\begin{array}{l}\text { HIV- } \\
\mathrm{I}_{\mathrm{NL4.3}}\end{array}$ & HUT78 & 1.11 & 1.18 & 1.34 & 0.96 & 1.35 & 1.13 & 2.20 & 1.20 & 1.38 & 1.05 & 12.90 \\
\hline $\begin{array}{l}\text { HIV- } \\
\mathrm{I}_{\mathrm{RFW}}\end{array}$ & HUT78 & 1.21 & 0.64 & 0.83 & 0.90 & 0.99 & 1.17 & 1.53 & 0.87 & 0.97 & 1.16 & 10.27 \\
\hline $\begin{array}{l}\text { HSV- } \\
I_{\mathrm{NCl}}\end{array}$ & HELA & 0.80 & 0.65 & 1.33 & 0.62 & 0.91 & 0.59 & 0.89 & 0.60 & 0.92 & 0.74 & 8.05 \\
\hline $\begin{array}{l}\text { HSV- } \\
\mathrm{I}_{\mathrm{NCl}}\end{array}$ & HEP2 & 0.41 & 0.42 & 0.44 & 0.50 & 0.37 & 0.38 & 0.60 & 0.41 & 0.57 & 0.54 & 4.64 \\
\hline $\begin{array}{l}\mathrm{VZV}_{\text {Schen }} \\
\text { ke }\end{array}$ & MDDC & 0.99 & 0.93 & 0.96 & 1.09 & 0.93 & 1.23 & 1.83 & 1.30 & 1.02 & 0.94 & 12.22 \\
\hline $\mathrm{VZV}_{\text {Schen }}$ & HFF & 1.56 & 1.09 & 1.12 & 1.34 & 1.45 & 1.75 & 1.94 & 1.87 & 1.70 & 1.54 & 15.36 \\
\hline cMe $\mathrm{VV}_{\text {Tow }}$ & HFF & 0.65 & 0.58 & 0.60 & 0.60 & 0.82 & 0.60 & 1.14 & 0.58 & 0.74 & 0.63 & 6.8 \\
\hline $\mathrm{CMV}_{\text {Tole }}$ & HFF & 0.86 & 0.61 & 0.75 & 0.76 & 0.71 & 0.90 & 1.22 & 0.73 & 0.86 & 0.77 & 7.87 \\
\hline & sum $_{v}$ & 9.41 & $7.4 I$ & 9.16 & 8.91 & 8.74 & 9.65 & 13.26 & 9.43 & 10.51 & 9.06 & \\
\hline
\end{tabular}

The standard deviations of reference gene expression as determined by GeNorm are shown. Abbreviations:. Sum ${ }_{v}:$ Sum of viral infection GeNorm values; sum $_{\mathrm{RGC}}$ : sum of reference gene GeNorm values.

Table 3: Reliability of references genes for each viral - cell pair

\begin{tabular}{|c|c|c|c|c|c|c|c|c|c|c|c|}
\hline Virus & HIV-I ${ }_{\mathrm{BaL}}$ & $\begin{array}{l}\text { HIV- } \\
\mathrm{I}_{\mathrm{NL4.3}}\end{array}$ & $\begin{array}{l}\text { HIV- } \\
\mathrm{I}_{\mathrm{NL4.3}}\end{array}$ & $\begin{array}{l}\text { HIV- } \\
I_{\text {RFW }}\end{array}$ & $\begin{array}{l}\text { HSV- } \\
\mathrm{I}_{\mathrm{NCI}}\end{array}$ & $\begin{array}{l}\text { HSV- } \\
\mathrm{I}_{\mathrm{NCI}}\end{array}$ & $\begin{array}{l}\text { VZV } \\
\text { nke }\end{array}$ & $\begin{array}{l}\mathbf{V Z V}_{\text {Sche }} \\
\text { nke }\end{array}$ & $\begin{array}{l}\text { CMV. } \\
\text { Towne }\end{array}$ & $\begin{array}{l}\text { CMV }_{\text {To- }} \\
\text { ledo }\end{array}$ & Overall \\
\hline Cell & MDDC & HELA & HUT78 & HUT78 & HELA & HEP2 & MDDC & HFF & HFF & HFF & - \\
\hline Ist & PPIA & PPIA & SDHA & PPIA & HMBS & HMBS & PPIA* & PPIA & PPIA* & PPIA & PPIA \\
\hline 2nd & GAPDH & GAPDH & TBP & EEFIG & PGKI & GAPDH & GAPDH* & EEFIG & PGKI* & GAPDH & GAPDH \\
\hline $3 r d$ & HMBS & TBP & B2M & PGKI & SDHA & PGK* & TBP & SDHA & $\begin{array}{l}\text { GAPDH* } \\
*\end{array}$ & PGKI & SDHA \\
\hline 4th & TBP & EEFIG & HMBS & SDHA & PPIA & B2M* & EEFIG & GAPDH & EEFIG** & EEFIG & TBP \\
\hline 5th & B2M & PGKI & PPIA & BACT & TBP & PPIA & B2M & TBP & SDHA** & SDHA & EEF IG \\
\hline 6th & I8sRNA & HMBS* & PGKI & GAPDH & B2M & EEFIG & BACT & B2M & TBP & TBP & B2M \\
\hline 7th & EEFIG & $\mathrm{B} 2 \mathrm{M}^{*}$ & EEFIG & TBP & I8sRNA & SDHA & SDHA & $\mathrm{BACT}$ & B2M & $\mathrm{B} 2 \mathrm{M}^{*}$ & PGKI \\
\hline 8th & PGKI & SDHA & GAPDH & HMBS & GAPDH & TBP & HMBS & HMBS & BACT & BACT* & HMBS \\
\hline 9th & SDHA & BACT & I8sRNA & B2M & BACT & BACT & PGKI & PGKI & HMBS & HMBS & BACT \\
\hline 10th & BACT & I8sRNA & BACT & I8sRNA & EEFIG & I8sRNA & I8sRNA & I8sRNA & I8sRNA & I8sRNA & I 8sRNA \\
\hline
\end{tabular}

Where two or more genes were equally reliable these are labelled with * or **.

viruses, probably reflecting variability in both virus strain and cell type. Notable differences included 18sRNA being a relatively reliable gene in MDDCs infected with $\mathrm{HIV}_{\mathrm{BaL}}$, but unreliable in other HIV infections and B2M being an unreliable reference gene in $\mathrm{HIV}-1_{\mathrm{RFW}}$ infected HUT78 cells only.

\section{Discussion}

There are now many reports describing the unreliability of conventionally used housekeeping genes for the normalisation of QPCR data in certain experimental settings $[4-7,14,15]$. Careful consideration must therefore be carried out when choosing appropriate reference genes in QPCR experiments and the reliability of a panel of potential genes should be determined for individual experimental conditions [3,8]. Ideally the best two or three of these genes would then be used for normalisation purposes [16]. This is of particular concern to molecular virologists as most viruses modulate key cellular processes which may involve changing the expression of QPCR reference genes. Different viruses manipulate different cellular transcription pathways and the extent to which these pathways are affected will be dependent on the specific 
strain of virus and the cell type infected. Thus it is not possible to identify a single housekeeping gene for use in QPCR studies of viral infections. Nevertheless it is of benefit for researchers to be able to determine a shortlist of potential candidates. To date the variability of housekeeping gene expression has been studied in cells infected with SARS corona virus, yellow fever virus, human herpes virus6, camelpox virus, CMV [7] and Epstein-Barr virus (EBV) [12]. However such a study has never been carried out using the key human pathogens HIV, HSV and VZV. Therefore in this study we have extended the published investigations by determining the suitability of 10 commonly used reference genes in the context of infection with various strains of HIV-1, HSV-1, CMV and VZV in a range of both primary and cultured cell lines using the GeNorm tool [13].

We found that overall 18sRNA was the least reliable gene studied and that BACT was also consistently unreliable. This correlates with the data from Radonic et al [7] who found BACT to be the most unreliable of 10 reference genes studied in a range of 5 viral infections. 18sRNA was not included in their study however. In contrast Bernasconi et al [12] found BACT had the lowest coefficient of variation of 451 housekeeping genes spotted on microarrays in EBV infection in B cells from patients with Burkitt's lymphoma. It is of note however that the $\gamma$-herpes virus EBV was not included in our study or of that of Radonic et al though the $\beta$-herpes virus $\mathrm{CMV}$ and $\alpha$-herpes viruses HSV-1 and VZV were. In agreement with Radonic et al we found that PP1A was the most reliable reference gene across all infections. However in contrast to their finding that TBP was equally reliable as PP1A we found it to be the $4^{\text {th }}$ most reliable gene. Other reliable genes identified by our study included GAPDH and SDHA.

A comprehensive literature review of expression studies published in high-impact journals found that GAPDH, BACT, 18sRNA and 28sRNA were used as a single control gene in $>90 \%$ of cases [13]. However, we found that two of these (18sRNA and BACT) were the least reliable in the context of the viral infections that we investigated. In contrast to all other infections, 18sRNA was not an unreliable control gene when MDDCs were infected with HIV- $1_{\mathrm{BaL}}$ In addition it is of note that although GAPDH was one of the most reliable reference genes identified overall, it was the third most unreliable gene in HELA cells infected with $\mathrm{HSV}-1_{\mathrm{NC} 1}$ (whereas it was the second most reliable reference gene in HEP2 cells infected with the same strain of HSV-1). These findings therefore highlight the importance of re-evaluating the choice housekeeping genes when making even slight changes to experimental settings.

\section{Conclusion}

In summary, PPIA, GAPDH and SDHA were the best QPCR control genes and we would recommend molecular virologists begin by short listing these genes when designing QPCR experiments. 18sRNA and BACT were consistently unreliable and should be used with caution in studies involving virally infected cells.

\section{Materials and methods Virus culture}

HSV-1 strain NC1, CMV strains Towne and Toledo, VZV strain Schenke and HIV-1 strains BaL, NL4.3 and RFW were propagated according to standard protocols [16-20]. The cell types infected, MOI, time of infection and percentage of cells infected are shown in table 1. Cells were infected with each virus strain at a MOI and duration in order to achieve the maximal percentage of infected cells as determined by QPCR for all HIV-1, HSV-1 and CMV infected cells, [21] and by flow cytometry for VZV infected cells [22].

\section{RNA extraction and DNase treatment}

Total RNA from cells derived from four independent experiments was extracted using the RNAqueous-Midi kit (Ambion, TA), quantified by UV spectroscopy and the integrity confirmed using an agilent 2100 bioanalyzer. $1 \mu \mathrm{g}$ of the total RNA was then DNase treated using $1 \mathrm{U}$ RNase free DNase (Promega, Madison WI).

\section{cDNA synthesis}

cDNA was produced using the Superscript III RT-PCR System (Invitrogen, Rockville, MD) according to the manufacturer's recommendations for oligo(dT)20 primed cDNA-synthesis. cDNA synthesis from RNA was performed using $1 \mu \mathrm{g}$ of RNA, at $50^{\circ} \mathrm{C}$. The cDNA was then treated with RNase $\mathrm{H}$ (Invitrogen) and diluted 1:100 before use for QPCR.

\section{Quantitative PCR}

In order to measure housekeeping gene expression, cDNA was subject to QPCR using the platinum QPCR super mix kit (Invitrogen) and pre-designed certified LUX primers (Invitrogen) designed to amplify the following transcripts: B2M, PPIA, EEF1G, SDHA, GAPDH, HMBS, TBP, 18sRNA, PGK1, BACT. Fluorescent PCR amplicons were detected using a Stratagene Mx3005 QPCR thermocycler using 96-well microtiter plates in a final volume of $25 \mu \mathrm{l}$ under the following cycle conditions: $50^{\circ} \mathrm{C}$ for 2 minutes, $95^{\circ} \mathrm{C}$ for 2 minute, 45 cycles of $95^{\circ} \mathrm{C}$ for 15 seconds $55^{\circ} \mathrm{C}$ for 30 seconds and $72^{\circ} \mathrm{C}$ for 30 seconds.

\section{Data analysis}

The $\Delta \Delta$ CT [23] method was used for initial data analysis. Four biological replicates were used for each infection and a two tailed test with a significance level of 5\% was used to measure the significance between sample replicates. Repeated measures analysis of variance was then used to test for the presence of interaction between the effects of 
the within experiment factors for housekeeping gene and viral status of the cell sample. Data analysis was also performed using the GeNorm tool [13].

\section{Abbreviations}

QPCR, quantitative PCR; CMV, cytomegalovirus; HSV, herpes simplex virus; VZV, varicella zoster virus; $\mathrm{B} 2 \mathrm{M}$, beta-2microglobulin; PP1A, peptidylprolyl isomerase A; EEF1G, eukaryotic translation elongation factor 1 gamma; SDHA, succinate dehydrogenase complex subunit A; GAPDH, glyceraldehyde 3-phosphate dehydrogenase; BACT, beta actin; HMBS, hydroxymethyl-bilane synthase; TBP, TATA box-binding protein; 18sRNA, 18s Ribosomal RNA; PGK1, phosphoglycerate kinase 1.

\section{Competing interests}

The author(s) declare that they have no competing interests.

\section{Authors' contributions}

$\mathrm{AH}, \mathrm{JW}, \mathrm{CB}$ and $\mathrm{AC}$ conceived of the study. AH designed and supervised the experiments, prepared the HIV infected MDDC extracts, and prepared the manuscript with CB. SW carried out the QPCR experiments and conducted data analysis with the help of SM. AC provided intellectual input, and grant funding. All authors read and approved the final manuscript.

\section{Acknowledgements}

We would like to thank the following members of the Centre for Virus Research for providing infected cell extracts and determining infectivity rates: Kavitha Gowrishankar and Elizabeth Sloan (VZV), Winnie Garcia (CMV), Debbie Ko (HSV-I), and Judith Edmonds, Sarah Sherwood, Sabine Piller and Valerie Marsden (HIV-I). The authors are grateful to Heather Donaghy for critical reading of the manuscript.

This project was supported by a National Health and Medical Research Council (NHMRC) Program Grant. ID number 358399.

\section{References}

I. Mackay IM, Arden KE, Nitsche A: Real-time PCR in virology. Nucleic Acids Res 2002, 30(6): 1292-1 305.

2. Pfaffl MW: A new mathematical model for relative quantification in real-time RT-PCR. Nucleic Acids Res 200I, 29(9):e45

3. Thellin O, Zorzi W, Lakaye B, De Borman B, Coumans B, Hennen G, Grisar T, lgout $A$, Heinen $E$ : Housekeeping genes as internal standards: use and limits. J Biotechnol 1999, 75(2-3):291-295.

4. Glare EM, Divjak M, Bailey MJ, Walters EH: beta-Actin and GAPDH housekeeping gene expression in asthmatic airways is variable and not suitable for normalising mRNA levels. Thorax 2002, 57(9):765-770.

5. Selvey S, Thompson EW, Matthaei K, Lea RA, Irving MG, Griffiths LR: Beta-actin-an unsuitable internal control for RT-PCR. Mol Cell Probes 200I, 15(5):307-3II.

6. Zhong $H$, Simons JW: Direct comparison of GAPDH, betaactin, cyclophilin, and 28S rRNA as internal standards for quantifying RNA levels under hypoxia. Biochem Biophys Res Commun 1999, 259(3):523-526.

7. Radonic A, Thulke S, Bae HG, Muller MA, Siegert W, Nitsche A: Reference gene selection for quantitative real-time PCR analysis in virus infected cells: SARS corona virus, Yellow fever virus, Human Herpesvirus-6, Camelpox virus and Cytomegalovirus infections. Virol J 2005, 2:7.
8. Radonic A, Thulke S, Mackay IM, Landt O, Siegert W, Nitsche A: Guideline to reference gene selection for quantitative realtime PCR. Biochem Biophys Res Commun 2004, 3 I 3(4):856-862.

9. Kalejta RF, Shenk T: Manipulation of the cell cycle by human cytomegalovirus. Front Biosci 2002, 7:d295-306.

10. Schang LM: The cell cycle, cyclin-dependent kinases, and viral infections: new horizons and unexpected connections. Prog Cell Cycle Res 2003, 5: 103-124.

II. Hayward SD, Liu J, Fujimuro M: Notch and Wnt signaling: mimicry and manipulation by gamma herpesviruses. SCi STKE 2006, 2006(335):re4.

12. Bernasconi M, Berger C, Sigrist JA, Bonanomi A, Sobek J, Niggli FK, Nadal D: Quantitative profiling of housekeeping and EpsteinBarr virus gene transcription in Burkitt lymphoma cell lines using an oligonucleotide microarray. Virol J 2006, 3:43.

13. Vandesompele J, De Preter K, Pattyn F, Poppe B, Van Roy N, De Paepe A, Speleman F: Accurate normalization of real-time quantitative RT-PCR data by geometric averaging of multiple internal control genes. Genome Biol 2002, 3(7): RESEARCH0034.

14. Hsiao LL, Dangond F, Yoshida T, Hong R, Jensen RV, Misra J, Dillon $W$, Lee KF, Clark KE, Haverty $P$, et al: A compendium of gene expression in normal human tissues. Physiol Genomics 200I, 7(2):97-104.

15. Warrington JA, Nair A, Mahadevappa M, Tsyganskaya M: Comparison of human adult and fetal expression and identification of 535 housekeeping/maintenance genes. Physiol Genomics 2000, 2(3): $143-147$

16. Harman AN, Wilkinson J, Bye CR, Bosnjak L, Stern JL, Nicholle M, Lai J, Cunningham AL: HIV induces maturation of monocytederived dendritic cells and Langerhans cells. J Immunol 2006, | 77( I 0):7|03-7||3.

17. Diefenbach RJ, Miranda-Saksena M, Diefenbach E, Holland DJ, Boadle RA, Armati PJ, Cunningham AL: Herpes simplex virus tegument protein USII interacts with conventional kinesin heavy chain. J Virol 2002, 76(7):3282-3291.

18. Willemsen NM, Hitchen EM, Bodetti T], Apolloni A, Warrilow D, Piller SC, Harrich D: Protein methylation is required to maintain optimal HIV-I infectivity. Retrovirology 2006, 3:92.

19. Gowrishankar K, Slobedman B, Cunningham AL, Miranda-Saksena M, Boadle RA, Abendroth A: Productive varicella-zoster virus infection of cultured intact human Ganglia. J Virol 2007, 8I ( I 2):6752-6756

20. Jones DR, Suzuki K, Piller SC: A I 00-amino acid truncation in the cytoplasmic tail of glycoprotein $4 \mathrm{I}$ in the reference HIV type I strain RF. AIDS Res Hum Retroviruses 2002, I8(7):5 I3-5 I7.

21. Roback JD, Hillyer CD, Drew WL, Laycock ME, Luka J, Mocarski ES, Slobedman B, Smith JW, Soderberg-Naucler C, Todd DS, et al:: Multicenter evaluation of PCR methods for detecting CMV DNA in blood donors. Transfusion 200I, 4 I (10): I 249-1257.

22. Morrow G, Slobedman B, Cunningham AL, Abendroth A: Varicellazoster virus productively infects mature dendritic cells and alters their immune function. J Virol 2003, 77(8):4950-4959.

23. Livak KJ, Schmittgen TD: Analysis of relative gene expression data using real-time quantitative PCR and the 2(-Delta Delta C(T)) Method. Methods 200I, 25(4):402-408.

Publish with Bio Med Central and every scientist can read your work free of charge

"BioMed Central will be the most significant development for disseminating the results of biomedical research in our lifetime. "

Sir Paul Nurse, Cancer Research UK

Your research papers will be:

- available free of charge to the entire biomedical community

- peer reviewed and published immediately upon acceptance

- cited in PubMed and archived on PubMed Central

- yours - you keep the copyright 